\title{
Transatlantica
}

Revue d'études américaines. American Studies Journal

\section{African American and Caribbean Literatures in}

\section{Belgium}

So Close, Yet So Far Apart

\section{Bénédicte Ledent}

\section{OpenEdition}

Journals

\section{Édition électronique}

URL : https://journals.openedition.org/transatlantica/4273

DOI : $10.4000 /$ transatlantica. 4273

ISSN : 1765-2766

Éditeur

Association française d'Etudes Américaines (AFEA)

\section{Référence électronique}

Bénédicte Ledent, «African American and Caribbean Literatures in Belgium », Transatlantica [En ligne], 1 | 2009, mis en ligne le 23 juin 2009, consulté le 15 septembre 2021. URL : http://

journals.openedition.org/transatlantica/4273; DOI : https://doi.org/10.4000/transatlantica.4273

Ce document a été généré automatiquement le 15 septembre 2021.

\section{c) (i) $९$}

Transatlantica - Revue d'études américaines est mise à disposition selon les termes de la licence Creative Commons Attribution - Pas d'Utilisation Commerciale - Pas de Modification 4.0 International. 


\title{
African American and Caribbean Literatures in Belgium
}

\author{
So Close, Yet So Far Apart ${ }^{1}$
}

Bénédicte Ledent

1 It has not been easy to collect information on African American research conducted in Belgium since the 1960s. In our country there has not been an undertaking of a size and scope comparable to what Michel and Geneviève Fabre have achieved in France, perhaps because Belgium is divided linguistically, with two communities, one Dutchspeaking, the other French-speaking, each with separate funding bodies, a situation that does not make national research projects easy to implement. This being said, however, the picture of how African American studies developed in Belgium is far from dull.

\section{Literary Endeavors}

2 The initiatives undertaken by Vik Doyen of the Catholic University of Leuven from the end of the 1970s, when he began teaching a seminar on African American literature, are worth highlighting. His endeavors were rewarded in 1997 with a well-attended conference, mostly with Belgian contributors, and a doctoral thesis on Toni Morrison by Kaat de Loof, whose jury included Michel Fabre. Of course, there have been other worthwhile Belgian achievements in the field, but they have not been part of a concerted effort to put African American studies on the research map, even though the situation is slowly changing, often under the impulse of single individuals. For example, Christophe Den Tandt, from Brussels Free University, who supervised the doctoral thesis of Patricia Muñoz-Cabrera on Toni Morrison and Gayl Jones, has started teaching a survey course on the African American novel. Importantly, many promising young scholars have started working in the discipline, sometimes even from the undergraduate level, by choosing African American topics for their final essays. For example, Edward Lybeer from Brussels Free University, who worked on the interface between jazz and poetry (and is now studying in the United States), and Cécile Rimbaud 
from the University of Liège, who also addressed jazz music, but this time in the fiction of Toni Morrison, a writer who has been very popular with young Belgian researchers, but also with more established scholars such as Kathleen Gyssels from the University of Antwerp, to whose work I will refer later.

3 At the doctoral level too, African American literature has aroused vocations. Chief among these young talents is probably Valérie Bada, who, n 2003, defended a dissertation entitled "Mnemopoetics: Memory and Slavery in African American Drama: 1939-1996" at the University of Liège, where she is now a Francophone Science Research Fund (FNRS) post-doctoral researcher and teaches a seminar in African American drama. Her thesis, dealing with playwrights such as Langston Hughes, Amiri Baraka and Rita Dove, has recently been published by Peter Lang in the series "Dramaturgies". With the exception of research conducted by Marc Maufort (from Brussels Free University) on August Wilson and Suzan-Lori Parks, African American drama had not been extensively studied in Belgium thus far. Bada's work therefore bodes well for the future of African American studies in Liège, where this literary tradition was first promoted in the 1990s by Christine Levecq, a Liège graduate now teaching at Kettering University in Flint, Michigan, who, like Bada, studied at one point at the WEB Du Bois Institute for African American Research at Harvard. After completing a doctoral thesis on Zora Neale Hurston at the University of Illinois at Urbana-Champaign, Levecq established an African American Literature seminar in Liège and worked on such writers as Ishmael Reed and Alice Walker. Again in the 1990s, but this time at the Catholic University of Louvain-la-Neuve, Chantal Zabus devoted some of her teaching to feminism in African-American writing.

\section{Research in Musicology}

Whereas most of the research and teaching endeavors mentioned above relate to contemporary, or recent, literature, there is another area of research that deserves to be examined: African American musicology. Its main representative at the Belgian level is Robert Sacré, also from the University of Liège. Sacré, whose seminars on African American music have been popular for several decades, is the author of several volumes, notably one on Negro Spirituals and Gospel Songs and another on music from Louisiana. ${ }^{3}$ In 1984 and 1991 he also organized international symposia in Liège, which led to the publication of noteworthy proceedings. ${ }^{4}$

It is of course difficult to isolate specific reasons why African American studies developed more in some universities than in others. Apart from the influence of dynamic individuals, library resources may have played an important role, although one could argue that the two factors are indissociable. In this respect, one should mention the collections of the Catholic University in Leuven and of the Center for American Studies in Brussels, as well as those of the University of Liège, which received a special grant from FNRS in the early 1990s to acquire a wide range of both primary and secondary source material. 


\section{Post-colonial Studies}

While the future of African American studies in Belgium seems secure, it is important to point out that their boundaries have lately become less clearly defined and that they have increasingly tended to overlap with post-colonial studies, in particular those from the Caribbean and its diaspora, a field of research well represented in Belgium, first and foremost at the University of Liège at once in terms of teaching, research and resources. More recently, the field has also become popular at the Catholic University of Louvain-la-Neuve and the University of Antwerp.

7 Caribbean Literature developed in Liège under the impulse of the late Professor Hena Maes-Jelinek, who was also one of Michel Fabre's friends. ${ }^{5} \mathrm{~A}$ true pioneer in her field, she started teaching West Indian literature in Liège at the end of the 1960s, at a time when no English university had a single Caribbean writer on their curriculum. Professor Maes-Jelinek devoted much of her impressive career to the work of Wilson Harris, a writer of Guyanese origin who is now taught in American universities and has influenced African American writers such as Nathaniel MacKey. Interestingly, Michel Fabre was also an admirer of Wilson Harris, whom he interviewed and whose work he commented upon on several occasions.

8 Hena Maes-Jelinek is reputed for the vigor and rigor of her research, but she is also known for an exceptional ability to encourage and motivate younger scholars and pass on the research "bug", not least by allowing them to meet writers and engage in a fruitful dialogue with them. ${ }^{6}$ In the 1970 s and 1980s, for example, she organized conferences in Liège with famous figures of Caribbean writing such as Edward Kamau Brathwaite and Wilson Harris. More recently, other conferences were convened in Liège under the aegis of the Centre for Commonwealth Studies, which she founded in the 1980s, and again well-known writers such as Erna Brodber, Fred D'Aguiar, Caryl Phillips, and Lawrence Scott addressed large audiences of motivated listeners.

\section{Interactive research}

Until the 1990s, African American and Caribbean literatures were mostly kept apart in Belgian universities, first of all for institutional reasons, since academic subjects are often delineated on a national basis, but also because of a more general lack of interaction among critics. Arguably, one cannot deny the commonalities between the two areas of study, not least a shared experience of homelessness and a common history of slavery and dispossession, which has led some scholars, such as Kathleen Gyssels in Antwerp, to explore these two literary traditions from a comparatist perspective. One of her books, entitled Sages Sorcières?, which brings together Toni

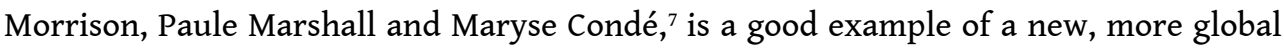
approach which crosses both national and linguistic barriers, and looks at African American and Caribbean literatures as products of the same diaspora. This transcultural approach, which was also adopted by Geneviève and Michel Fabre in France and is exemplified by journals such as Callaloo, is the hallmark of the "PostColonial Research Group" that Gyssels has founded at the University of Antwerp and which in 2003 organized a multi-lingual conference on "The Caribbean Writer as Warrior of the Imaginary". 


\section{An Erasure of Specificities?}

10

have been so far mostly analyzed separately, the growing interaction between them, which was also promoted by the publication of Paul Gilroy's The Black Atlantic in 1993, is to be welcomed for a number of reasons. And mainly because it can open onto new critical vistas and promote an exchange going in both directions. For example, the extensive theoretical production on African American writing can be useful to scholars of Caribbean literature, while essays by creative writers such as Edouard Glissant and Wilson Harris, who have much in common, can enrich the work of critics studying Black American artists. This being said, however, such an opening can also have less desirable side-effects, among others the erasure of the specificities that have shaped these two fields in crucial ways. For example, the Caribbean interpretation of "race" has always been informed by a sense of 'impurity' inherited from history while the African American stance has generally been more radical, imbued as it was by a more confrontational and militant perception of the racial divide. So, for all the attendant benefits, bringing the two fields together indiscriminately could lead to the wholesale annexation - perhaps even "colonization"? - of Caribbean literature by African American studies, which is already happening in published anthologies, for example. The best proof of this is the second edition of the Norton Anthology of African American Literature, edited by Henry Louis Gates, which includes Caribbean writers based in the United States, such as Michelle Cliff, Edwidge Danticat, Jamaica Kincaid and Caryl Phillips. The danger of the absorption of the Caribbean field is all the more real as African American studies are often generously funded, which is rarely the case for Caribbean studies (see, for example, the Caribbean seminar at the University of Miami, which disappeared, apparently because of a lack of funding).

11 I would like to conclude by illustrating this point about the relationship between African American and Caribbean studies with a few words about Caryl Phillips, the writer on whom I wrote my doctoral dissertation for the University of Liège in the 1990s and on whom I have regularly published since. Like other writers before him, for example Claude McKay or Paule Marshall, Phillips, a writer born in St. Kitts, brought up and educated in England and now a resident in New York, is at the crossroads of several traditions, including the Caribbean and the African American ones. It would certainly be difficult to ignore the role played by African American literature in Phillips's career. However, I would like to argue that he cannot be unproblematically recruited under the African American banner and that his writing remains crucially shaped by his native Caribbean background, a fact that might be overlooked if he were seen only as an African American writer or simply as a writer of the Diaspora.

12 Arguably, it is almost impossible to examine Phillips's work without taking its AfricanAmerican dimension into account, regardless of the fact that he has now lived in the United States for almost eighteen years. Already in The European Tribe (1987), an account of his journey through a racist Europe, Phillips acknowledged his debt to African American writers, in particular to Richard Wright (one of Michel Fabre's favorite authors), thanks to whom the Kittitian novelist was able to realize "that it was possible for a black person to become, and sustain a career as a writer." ${ }^{8}$ It would indeed be hard to imagine what Phillips's career would have been like without the 
formative influence of Wright, and also of James Baldwin and Toni Morrison. Moreover, like several other Caribbean writers, including Erna Brodber in Louisiana (1994) or Michelle Cliff in Free Enterprise (1993), Phillips has suggested in his fiction, notably in Higher Ground (1989) and in Crossing the River (1993) - which seems to me his most American novel to date - how close the African American experience is to that of the Caribbean. He puts as much in the mouth of Rudy, a young prison inmate in Higher Ground:

I have made a pledge that one day we must visit our cousins in the West Indies. Their history is our history for they too are African people captured and sold into American bondage. They were shipwrecked on American islands, we on the American mainland. While the white men who 'owned' us became American, their white men remained Europeans: French, English, Spanish or Dutch. The African West Indian is a captive within a captive and colonial society. We are captives in a supposedly free society. But we are historically of the same blood. What is inimical to them is inimical to us also. ${ }^{9}$

Phillips does not directly question this recognition of commonalities between the two communities in this early text, in spite of the racial bigotry of the character who expresses this idea. It is only in a novel published in 2005, Dancing in the Dark, which is set mostly in New York at the turn of the twentieth century and focuses on the tragic life of Caribbean-born entertainer Bert Williams, that Phillips tackles this question in a more straightforward manner, notably by contrasting Bert's take on race with that of his African American partner George Walker, two different approaches which seem to be at least partly shaped by the two men's different origins. While Bert, as a West Indian immigrant, is ready to compromise and prefers "the quieter way," ${ }^{10}$ George is racially more confident and therefore more radical.

14 Such a cultural difference makes me uneasy when I see Phillips incorporated into African American literature, as is the case, for example, in a collection by Rebecca Carroll entitled Swing Low: Black Men Writing. ${ }^{11}$ Or when I read, from the pen of Darryl Pinckney in Out There: Mavericks of Black Literature, that Phillips's "internationalism was derived from the African American writers of his supplementary reading. [...] They taught [him] how to turn feeling dispossessed into a cultural advantage, a point of view". ${ }^{12}$ While there might be some ground to the former classification and to the latter statement, these two examples also seem to overlook that Phillips's writing springs from a typically Caribbean sense of plural, fluid and impure identity which gave him what he calls "the gift of displacement." ${ }^{13}$ This differs quite markedly from what Phillips has described in a article published in 2003 as the "tribalism" that, for him, characterizes race relations in the United States of America. ${ }^{14}$ In his collection of essays entitled A New World Order, he concludes a piece on America, significantly entitled "The Burden of Race," by the telling thought: "Race matters. Sure it does, but not that much." ${ }^{15}$ As he suggests in his work, the best way of escaping what he views as "the restrictive noose of race" 16 would be to refer to the "synthesising new world vision" 17 provided by the Caribbean, a world vision that could perhaps become a model, however imperfect and ambiguous, for Europe and the United States.

These differences between the various branches of the African diaspora are raised by a novel that played an important role in Michel Fabre's career as critic, teacher and cultural facilitator: Claude McKay's Banjo (1928), a text which he not only discussed extensively, ${ }^{18}$ but also translated into French at the end of the 1990 s. ${ }^{19}$ While this testifies to Michel Fabre's legendary generosity in sharing his literary passions, his 
early interest in Banjo also demonstrates his perceptiveness in spotting texts that were to become significant. Banjo, which depicts a group of men of African descent who drift around the Marseilles waterfront in the 1920s, is now regarded as a key text because, to quote Caryl Phillips again, "it has all the elements that are now being examined and looked at and dissected by late 20th, early 21st century scholars of Colonialism and Postcolonialism. It's all there in Banjo-but sixty, seventy years ago." ${ }^{20}$ One finds the same perspicacity in the attention that Michel Fabre paid to Sam Selvon's The Lonely Londoners and to many other texts that he helped European scholars to discover. To me, therein lies his most important legacy.

\section{BIBLIOGRAPHIE}

BADA, Valérie. Mnemopoetics: Memory and Slavery in African American Drama, Brussels: P.I.E. Peter Lang, 2008.

CARROLL, Rebecca. "Caryl Phillips," 161-176 in Swing Low: Black Men Writing, Rebecca Carroll, ed., New York: Crown Trade, 1995.

FABRE, Michel. From Harlem to Paris: Black American Writers in France, 1840-1980, Urbana and Chicago: University of Illinois Press, 1991.

-------, “Claude McKay and the Two Faces of France," 92-113 in From Harlem to Paris: Black American Writers in France, 1840-1980, Missouri Botanical Garden, Michel Fabre, ed., Urbana and Chicago: University of Illinois Press, 1991.

GYSSELS, Kathleen. Sages Sorcières ? Révision de la mauvaise mère dans Beloved (Toni Morrison), Praisesong for the Widow (Paule Marshall), et Moi, Tituba, sorcière noire de Salem (Maryse Condé), Lanham/New York/Oxford: University Press of America, 2001.

-------, Passes et impasses du comparatisme postcolonial, Paris: Honoré Champion, forthcoming. MAS-JELINEK, Hena. "Writing and the Other Arts in Wilson Harris's Fiction," 17-26 in Places of Memory: Essays in Honour of Michel Fabre. Commonwealth. Essays and Studies, SP 5, 2003.

------, "Postcolonial Criticism at the Crossroads: Subjective Questionings of an Old-Timer," 1-19 in Towards a Transcultural Future: Literary and Society in a 'Post'-Colonial World, Geoffrey V. Davis et al., eds., Amsterdam/New York: Rodopi, 2004.

PHILLIPS, Caryl. The European Tribe, London: Faber \& Faber, 1987.

-------, Higher Ground, London: Viking, 1989.

------, A New World Order, London: Secker \& Warburg, 2001.

-------, “American Tribalism," 87-91 in The American Effect: Global Perspectives on the United States, 1990-2003, Lawrence Rinder, ed., New York: Whitney Museum of American Art, 2003.

-------, Dancing in the Dark, London: Secker \& Warburg, 2005.

PINCKNEY, Darryl. Out There : Mavericks of Black Literature, New York: Basic Civitas, 2002. 
SACRE, Robert, ed., Charley Patton, The Voice of the Delta -The Mississippi Delta Blues

Traditions : A Symposium, Liège : Presses Universitaires de Liège, 1987.

------, Les Negro Spirituals et les Gospel Songs, Paris : PUF, Que sais-je ?, 1993.

-------, Musique cajun, créole et zydeco de Louisiane, Paris : PUF, Que sais-je ?, 1995.

-------, Saints and Sinners : Blues (D)Evil and Religion in African American Music and Literature, Liège : Société Liégeoise de Musicologie, 1996.

VINUESA, Maya G. "Afroeuropa in Conversation with Caryl Phillips," AFROEUROPA: Journal of Afroeuropean Studies, 1.3 (2007).

$\underline{\text { http://journal.afroeuropa.eu/index.php/afroeuropa/article/view/41/64 }}$

\section{NOTES}

1. An earlier version of this paper was delivered at the conference held in honor of Michel Fabre and Geneviève Fabre at the Université de la Sorbonne Nouvelle - Paris III from 15 to 18 December 2004. The conference was entitled: "African American and Diasporic Research in Europe: Comparative and Interdisciplinary Approaches."

2. Valérie Bada, Mnemopoetics: Memory and Slavery in African American Drama (Brussels: P.I.E. Peter Lang, 2008).

3. Robert Sacré, Les Negro Spirituals et les Gospel Songs (Paris : PUF, Que sais-je ?, 1993) and Musique cajun, créole et zydeco de Louisiane (Paris : PUF, Que sais-je ?, 1995).

4. Robert Sacré, ed., Charley Patton, The Voice of the Delta -The Mississippi Delta Blues Traditions : A Symposium (Liège : Presses Universitaires de Liège, 1987) and Saints and Sinners: Blues (D)Evil and Religion in African American Music and Literature (Liège : Société Liégeoise de Musicologie, 1996).

5. In 2003 she contributed to a volume of essays in honor of Michel Fabre with a paper entitled "Writing and the Other Arts in Wilson Harris's Fiction." See Places of Memory: Essays in Honour of Michel Fabre. Commonwealth. Essays and Studies, SP 5 (2003), pp. 17-26.

6. See Hena Maes-Jelinek, "Postcolonial Criticism at the Crossroads: Subjective Questionings of an Old-Timer", 1-19 in Towards a Transcultural Future: Literary and Society in a 'Post'-Colonial World, Geoffrey V. Davis et al., eds. (Amsterdam/New York: Rodopi, 2004).

7. Kathleen Gyssels, Sages Sorcières? Révision de la mauvaise mère dans Beloved (Toni Morrison), Praisesong for the Widow (Paule Marshall), et Moi, Tituba, sorcière noire de Salem (Maryse Condé), (Lanham/New York/Oxford: University Press of America, 2001). See also her forthcoming book, Passes et impasses du comparatisme postcolonial (Paris: Honoré Champion).

8. Caryl Phillips, The European Tribe (London: Faber \& Faber, 1987), p. 1.

9. Caryl Phillips, Higher Ground (London: Viking, 1989), p. 123.

10. Caryl Phillips, Dancing in the Dark (London: Secker \& Warburg, 2005), p. 111.

11. Rebecca Carroll, "Caryl Phillips," in Swing Low: Black Men Writing (New York: Crown Trade, 1995), p. 161-176.

12. Darryl Pinckney, Out There: Mavericks of Black Literature (New York : BasicCivitas, 2002), pp. 124-125.

13. See the title of the chapter devoted to Phillips's Caribbean origins in A New World Order (London: Secker \& Warburg, 2001), pp. 129-134.

14. Caryl Phillips, "American Tribalism," in The American Effect: Global Perspectives on the United States, 1990-2003, ed. Lawrence Rinder (New York: Whitney Museum of American Art, 2003), pp. 87-91.

15. Phillips, A New World Order, pp. 9-17 (p. 17). 
16. Phillips, A New World Order, p. 131.

17. Phillips, A New World Order, p. 132.

18. See, for example, Michel Fabre, "Claude McKay and the Two Faces of France," in his From Harlem to Paris: Black American Writers in France, 1840-1980 (Urbana and Chicago: University of Illinois Press, 1991), pp. 92-113.

19. Claude McKay, Banjo (New York: Harper \& Brothers, 1929). Banjo, tr. Michel Fabre (Paris: André Dimanche, 1999).

20. Maya G. Vinuesa, "Afroeuropa in Conversation with Caryl Phillips," AFROEUROPA: Journal of Afroeuropean Studies, 1.3 (2007), http://journal.afroeuropa.eu/index.php/afroeuropa/article/ view/41/64

\section{AUTEUR}

\section{BÉNÉDICTE LEDENT}

University of Liège, Belgium 